\title{
Utilization of the Western Juniper (Juniperus occidentalis) in Strandboards to Improve the Decay Resistance
}

\author{
Tomáš Pipíška, ${ }^{\mathrm{a}, *}$ Jed Cappellazzi, ${ }^{\mathrm{a}}$ Scott Leavengood, ${ }^{\mathrm{a}}$ Frederick A. Kamke, ${ }^{\mathrm{a}}$ \\ Gerald Presley, ${ }^{a}$ and David Děcký ${ }^{b}$
}

\begin{abstract}
Naturally durable wood species such as western juniper (Juniperus occidentalis) are a potential source of bio-based wood preservatives for the improvement of non-durable timber species. This research investigated the durability of southern yellow pine (Pinus sp.) and western juniper lumber or strandboard. Single layer panels were made with six different types of wood or wood treatments: southern yellow pine, mixed juniper sapwood and heartwood, sapwood, heartwood, sapwood strands impregnated with juniper oil prior to and after panel manufacturing. Panels were fabricated with $560 \mathrm{~kg} / \mathrm{m}^{3}$ oven-dry density with $5 \%$ of PF resin and $0.5 \%$ of wax. Durability testing was performed with the brown rot fungi Gloeophyllum trabeum and Rhodonia placenta and the white rot fungus Trametes versicolor. Internal bond as a crucial parameter of OSB was measured. Tests revealed that juniper heartwood and juniper heartwood strandboards were highly decay resistant, and juniper oil pre- and postimpregnation strandboard manufacture imparted increased resistance to decay against one brown rot fungus, Gloeophyllum trabeum. Juniper strandboard manufactured from non-impregnated strands showed significantly higher internal bond than pine. These results suggest there is excellent potential for manufacturing highly decay-resistant OSB from juniper, especially from heartwood and that juniper oil can increase the durability of juniper sapwood strandboard.
\end{abstract}

Keywords: Natural durability; Western juniper; Strandboard; Decay resistance; Internal bond

Contact information: a: Department of Wood Science and Engineering, Oregon State University, 119 Richardson Hall, 3180 SW Jefferson Way, Corvallis, OR 97331, USA; b: Department of Wood Science and Technology, Faculty of Forestry and Wood Technology, Mendel University in Brno, Zemědělská 3, 61300 Brno, Czech Republic; *Corresponding author: tpipiska@gmail.com

\section{INTRODUCTION}

Western juniper (Juniperus occidentalis Hook.) is an invasive tree species that is widespread in the western United States including Oregon, California, Washington, Idaho, and Nevada (Bedell et al. 1993; Swan 1995; Gedney et al. 1999). The wood has an average density of $497 \mathrm{~kg} / \mathrm{m}^{3}$, with yellow sapwood and aromatic rose-red heartwood that is commonly used to manufacture posts, poles, fencing, decking, and other products (Panshin and Zeeuw 1980; Swan and Connolly 1998). The heartwood is highly decay-resistant and can remain in-service for 56 years or more without preservative treatment (Hemmerly 1970; Highley 1995; Swan 1995; Morrell and Schneider 1999; Morrell 2011; Kirker et al. 2013; Adams 2014). The durability of juniper heartwood is attributed to the high lignin content and presence of the cedrol and other terpenes that can be extracted by steam distillation (Kurth and Ross 1954; Adams 1987; Highley 1995). Sapwood has little inherent 
durability, but some data suggest that juniper sapwood adjacent to heartwood is more durable than sapwood further removed from the heartwood (Morrell 2011).

Manufacturing lumber from these highly tapered trees with many small branches results in extensive waste material as low-quality logs, slabs, branches, and foliage. In addition to low-value uses like firewood, waste materials may be used to manufacture strandboard with high decay-resistance. Developing higher value end-uses for juniper processing wastes would help improve the economic viability of lumber production for this species.

Substantial residual juniper foliage can be generated during harvesting with little utilizable value; however, juniper foliage is a rich source of biocidal terpenes, some of which impart durability to juniper heartwood (Acda et al. 1998). Extracts of juniper foliage and heartwood have activity against fungi and subterranean termites (Adams et al. 1988; Sichamba et al. 2012; Ateş et al. 2015; Scouse et al. 2015; Lipeh et al. 2020). Impregnating juniper wood with juniper essential oil diluted in a solvent to improve the decay-resistance of slabs/branches (primarily sapwood) can be an avenue to utilize the entire tree in the manufacture of a highly decay-resistant strandboard.

Wood decay that leads to strength loss is predominantly caused by basidiomycete fungi, which can be grouped into two main categories, lignin-degrading white-rot and carbohydrate-selective brown-rot (Zabel and Morrell 2020). These two types of fungi differ in what components they are able to degrade in wood, which stems from a difference in the genetic and enzymatic profiles (Floudas et al. 2012). The physiology of these two groups of fungi is different enough for them to both be included in standard durability testing protocols. White rot fungi are capable of depolymerizing all major cell wall components (lignin, cellulose, and hemicelluloses), primarily attack hardwoods, and the resultant wood tends to be spongy. Brown rot fungi mainly depolymerize cellulose and hemicelluloses, primarily attack softwoods, and leave decayed wood looking brown, brittle and fractured into distinct zones (Goodell et al. 2020; Zabel and Morrell 2020).

Natural durability (decay resistance) is defined here as "the inherent resistance of wood to fungal attack" (Scheffer and Morrell 1998). The utilization of naturally occurring wood extractives/oils from unused harvest residues to enhance the durability of the less decay-resistant sapwood is a bio-based alternative to other chemical treatment methods. Treatment with juniper oil may potentially redistribute the natural durability, thereby generating a greater amount of durable wood from western juniper harvest. This study explored ways in which the whole juniper tree (foliage, branches, logs) could be utilized to enhance the natural durability of engineered juniper strandboard for use in highly exposed applications. Therefore, the specific research objectives were: (1) to assess the durability of five strandboard panel types against decay fungi in laboratory microcosms measured by weight loss, and (2) to assess possible impacts of juniper oil impregnation on the internal bond properties of the strandboard.

\section{EXPERIMENTAL}

\section{Manufacturing}

Slabs containing sapwood and heartwood of western juniper were obtained from two different locations in Oregon. Materials were cut to the length $117 \mathrm{~mm}$ and submerged in water at $30{ }^{\circ} \mathrm{C}$ for $72 \mathrm{~h}$ as a plasticization step before cutting strands. Juniper blocks were cut into strands varying in thickness from 0.6 to $0.9 \mathrm{~mm}$ using a veneer slicer. Strands 
were dried in a rotary drier at $50{ }^{\circ} \mathrm{C}$ until they reached a moisture content of $4 \pm 1 \%$. Southern yellow pine strands were obtained from an OSB mill in Alabama with average dimensions of $0.6 \times 25 \times 117 \mathrm{~mm}$ (thickness $\times$ width $\times$ length).

Solid wood and a variety of strandboard specimens were milled and are described in Table 1. Seven control/baseline treatments were included to assess the ability of each test fungus to decay untreated southern yellow pine (Pine-W), the inherent decay resistance of natural juniper sapwood (Sap-W) and heartwood (Heart-W), and the inherent decay resistance of each type of untreated strandboard, including southern yellow pine (Pine-S), mixed juniper sapwood and heartwood (Mix-S), juniper sapwood (Sap-S), and juniper heartwood (Heart-S). The final two treatments were assessed to measure the durability of sapwood juniper strandboards impregnated with juniper oil in strands prior to panel pressing (Pre-S) and panels after pressing (Post-S). The Pre-S and Post-S samples were of interest to explore whether juniper oil would be volatilized by the high pressing temperatures.

\section{Impregnation}

Impregnation processes were made on both the juniper strands and strandboard. Strands and panels were oven-dried at $103{ }^{\circ} \mathrm{C}$ for $24 \mathrm{~h}$, cooled in a desiccator, and weighed. Western juniper oil (High Country Essential Oils, Fort Jones, CA) was diluted to 10\% ( $\mathrm{vol} / \mathrm{vol}$ ) in $95 \%$ ethanol. Specimens were soaked in the dilute oil solution and kept under vacuum $(70 \mathrm{kPa})$ for $30 \mathrm{~min}$. Afterward, the vacuum was released, and the specimens remained submerged in solution for an additional $30 \mathrm{~min}$. Then they were removed and weighed. Strands were oven-dried at $90{ }^{\circ} \mathrm{C}$ for $60 \mathrm{~min}$, and strandboard was dried in the hot press at $0.5 \mathrm{MPa}$ and $90{ }^{\circ} \mathrm{C}$ for $60 \mathrm{~min}$.

Panels were made using liquid phenol formaldehyde (PF) resin (GP 265C08 with 49\% resin solids, Georgia Pacific Chemicals, Atlanta, GA) with 5\% resin solids by weight and $0.5 \%$ wax added. Resin was sprayed with a spinning disk atomizer (Model EL-4, Coil Manufacturing, Surrey, Canada) at 10,000 rpm. Three panels with an average density 560 $\mathrm{kg} / \mathrm{m}^{3}$ and dimensions $8 \times 254 \times 254 \mathrm{~mm}$ (thickness $\times$ width $\times$ length) were fabricated in each group. Single layer strandboard panels were formed on wire mesh without any attempt to orient strands. Panels were pressed at $120^{\circ} \mathrm{C}$ with 30 seconds of closing, 240 seconds at position, and 40 seconds to vent. Following panel preparation, decay tests were performed similarly for all solid wood samples and panels.

\section{Testing Procedures}

\section{Decay test}

Ten replicates per treatment were oven-dried at $50{ }^{\circ} \mathrm{C}$ for $48 \mathrm{~h}$ and weighed to the nearest $0.001 \mathrm{~g}$. Samples were soaked in distilled water until their moisture contents reached $30 \%$ to $40 \%$, placed into individual plastic bags, and sterilized by exposure to 2.5 mrad of ionizing gamma radiation from a cobalt 60 source at the Oregon State University Radiation Center (Corvallis, OR). Resistance to fungal decay was assessed according to procedures described in the American Wood Protection Association (AWPA) Standard E10-16 (2020).

Briefly, decay chambers ( $473 \mathrm{~mL}$ French squares) were half-filled with a custom soil blend of $45 \%$ sandy loam soil (40\% sand, $40 \%$ silt, and $20 \%$ clay), $42 \%$ organic amendments ( $\sim 14 \%$ each of composted dairy manure, horse manure, and Douglas-fir bark) and $\sim 13 \%$ organic soil building conditioner (Gardner and Bloome ${ }^{\circledR}$, Carson, CA, USA). Strips of western hemlock (Tsuga heterophylla (Raf) Sarg.) for brown rot or red alder 
(Alnus rubra Bong) for white rot test fungi were placed on the soil surface, and the bottles were autoclave sterilized at $121{ }^{\circ} \mathrm{C}$ for $100 \mathrm{~min}$. The bottles were inoculated with $5 \mathrm{~mm}$ malt agar disks from the actively growing edges of cultures for the two brown rot fungi Gloeophyllum trabeum (Pers.: Fr.) Murr. (isolate \# Madison 617) and Rhodonia placenta (Fr) Niemela, Larss, and Schagel (Isolate No. Mad 698) or the white rot fungus Trametes versicolor (L. ex Fr.) Pilát (Isolate \# R-105). Inoculated bottles were incubated at $28{ }^{\circ} \mathrm{C}$ until test fungi completely covered the feeder strips ( $\sim 10$ days). Sterile test samples were then placed on the surfaces of the feeder strips. The bottles were loosely capped and incubated at $28{ }^{\circ} \mathrm{C}$ for 12 or 16 weeks for blocks exposed to brown or white rot fungi, respectively. Non-fungal exposed controls were included to provide a measure of mass losses that occur from block handling.

At the end of the incubation period, samples were removed, scraped clean of adhering mycelium, and weighed to determine moisture content at harvest. The samples were then oven-dried at $50{ }^{\circ} \mathrm{C}$ for $72 \mathrm{~h}$ and reweighed to determine mass loss. The difference between initial and final oven-dry weight was used as a measure of the decay resistance of each material. The degree of resistance to fungal attack was assessed using the scale described in ASTM D2017-05 (2014), where 0 to 10\% weight loss is considered highly resistant to decay, 11 to $24 \%$ weight loss is resistant, 25 to $44 \%$ is moderately resistant, and $>45 \%$ is slightly or non-resistant.

Table 1. Specimens for Testing Resistance to Brown and White Rot Fungi

\begin{tabular}{|l|l|c|l|}
\hline Sample Type & \multicolumn{1}{|c|}{ Treatment Description } & $\begin{array}{c}\text { Sample } \\
\text { Dimensions }\end{array}$ & Identifier \\
\hline \multirow{4}{*}{ Natural wood } & Southern yellow pine & $19 \mathrm{~mm}^{3}$ & Pine-W \\
\cline { 2 - 4 } & Juniper sapwood & $19 \mathrm{~mm}^{3}$ & Sap-W \\
\cline { 2 - 4 } & Juniper heartwood & $19 \mathrm{~mm}^{3}$ & Heart-W \\
\hline \multirow{4}{*}{ Strandboard } & Southern yellow pine & $19 \times 19 \times 9 \mathrm{~mm}$ & Pine-S \\
\cline { 2 - 4 } & Juniper (sap/heart mixed) & $19 \times 19 \times 9 \mathrm{~mm}$ & Mix-S \\
\cline { 2 - 4 } & Juniper sapwood & $19 \times 19 \times 12 \mathrm{~mm}$ & Sap-S \\
\cline { 2 - 4 } & Juniper heartwood & $19 \times 19 \times 12 \mathrm{~mm}$ & Heart-S \\
\cline { 2 - 4 } & Pre impregnated sapwood strands & $19 \times 19 \times 9 \mathrm{~mm}$ & Pre-S \\
\cline { 2 - 4 } & Post Impregnated sapwood panel & $19 \times 19 \times 9 \mathrm{~mm}$ & Post-S \\
\hline
\end{tabular}

\section{Mechanical properties}

Internal bond strength (IB) was measured on an Instron 5582 universal testing machine with a $100 \mathrm{kN}$ load cell (Waltham, MA, USA) for ten strandboard specimens with dimensions $50 \times 50 \mathrm{~mm}$ following ASTM D1037-12 (2020).

\section{Statistical Analysis}

The data were processed in STATISTICA 10 software (StatSoft Inc., Tulsa, OK, USA) and evaluated using a one-factor analysis of variance (ANOVA) and Tukey's honest significance test (HSD test) to explore differences in weight loss and internal bond strength. 


\section{RESULTS AND DISCUSSION}

Weight percent gain (WPG) of strands and strandboards treated with the essential oil diluted in the ethanol was $147.2 \%$ and $59.3 \%$ for strands and strandboards after soaking. Final WPG of the essential oil was $3.1 \%$ and $3.3 \%$ for strands and strandboards after drying, respectively.

Southern yellow pine strandboards exposed to $R$. placenta experienced average weight losses of $40.8 \%$ and weight losses for juniper strandboards were about $2.5 \%$. Based on these results, the former were moderately resistant to decay, and the latter were highly resistant, according to the guidelines in the ASTM D2017-05 (2014). The heartwood of juniper contains cedrol, widdrol, and other sesquiterpene alcohol compounds that show strong termiticidal and antifungal properties (Orejuela 1995; Craig et al. 2004; Mun and Prewitt 2011). The presence of biocidal terpenes in the wood, along with other properties, such as high lignin content, were likely major contributors to the high decay resistance of juniper strandboards.

Wood samples exposed to G. trabeum showed higher weight losses in comparison to the other fungi. Pine-W and Sap-W showed comparable weight losses of about $44 \%$, which is also comparable with the results of Miyamoto et al. (2019), where southern pine wood lost $42.6 \%$ of its mass exposed to G. trabeum. The highest weight loss, $64.3 \%$, was seen in the southern yellow pine strandboards, which is about 21 times higher than weight loss on the heartwood strandboards, in line with previous observations for similar materials (Wan et al. 2007). All of the juniper strandboards had significantly lower weight loss for $G$. trabeum than the southern yellow pine strandboards.

Weight loss for T. versicolor on the Pine-W was $26.2 \%$ and on juniper heartwood (Heart-W) was $0.2 \%$, which is comparable with the results of Miyamoto et al. (2019), $32.2 \%$ and $1.2 \%$ for pine and juniper respectively. Juniper heartwood strandboards exposed to $T$. versicolor showed an average weight loss of $1.1 \%$, which was the lowest value for strandboards. Other strandboards made from juniper and pine had statistically similar results, with higher average values for impregnated specimens (Pre-S, Post-S). Wan et al. (2007) reported strandboards with surface layers of the eastern white-cedar and aspen core layer showed weight losses of about $18.5 \%$ under $T$. versicolor, which is slightly lower than results here.

Impregnation of strands with juniper oil before and after pressing resulted in variable performance among the different decay fungi. The addition of oil appeared to be more effective at inhibiting the growth of brown rot fungi than white rot fungi, as shown by the mass losses near the uninoculated control for oil impregnated panels for Rhodonia placenta. The white rot fungus Trametes versicolor caused greater weight loss on impregnated panels than juniper sapwood alone. White rot fungi differ from brown rot fungi in that they produce lignin-degrading peroxidases which utilize a non-specific free radical mechanism to oxidize a wide variety of structural moieties in lignin (Kues 2015). This non-specificity enables white rot fungi to chemically modify a variety of xenobiotic compounds, including plant-based terpenes (Lee et al. 2015). This ability may have led to the higher mass losses for impregnated panels for Trametes versicolor than the brown rot species. 


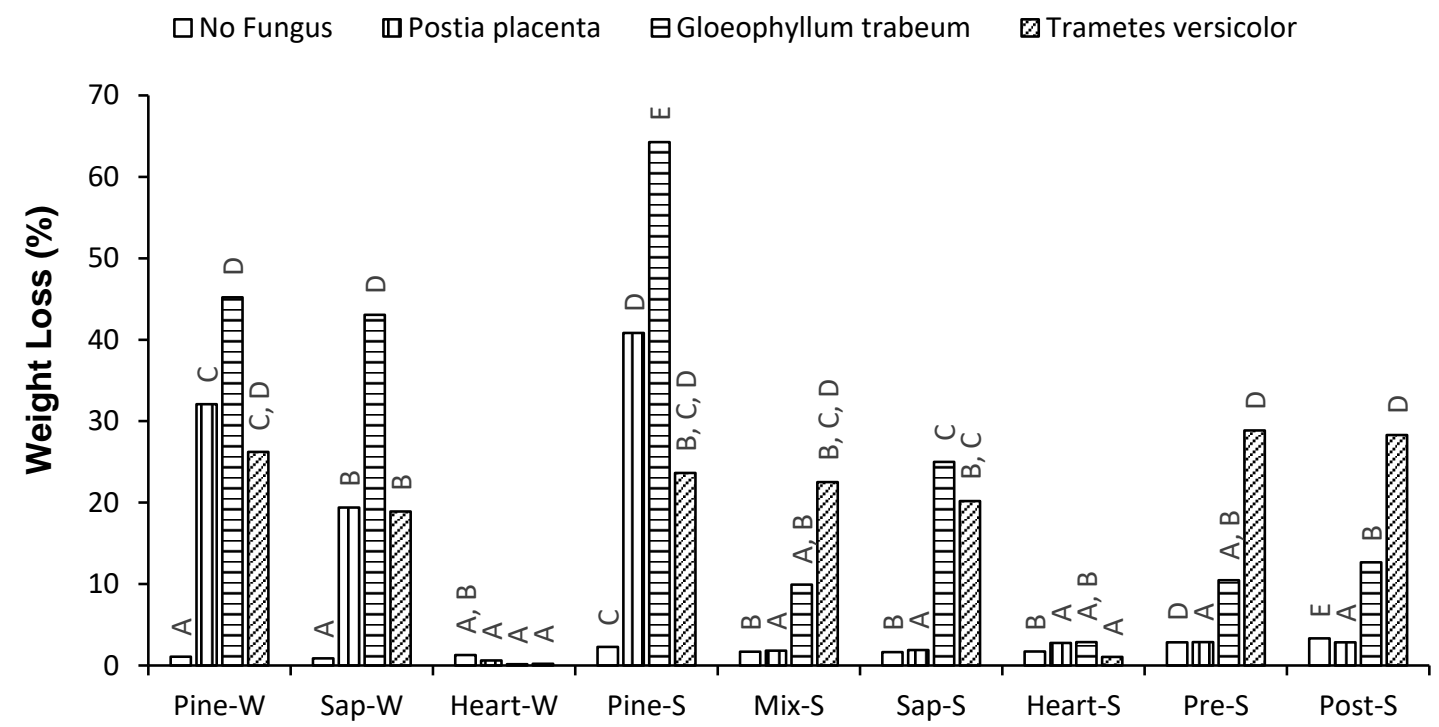

Fig. 1. Weight loss of the wood and strandboard exposed to the different fungi after 12 or 16 weeks for blocks exposed to brown or white rot fungi, respectively

The average internal bond strength values for strandboards are shown in Table 2. The previously reported average internal bond strength for strandboard $\left(624 \mathrm{~kg} / \mathrm{m}^{3}\right)$, with surface layer of eastern white-cedar and aspen core layer (2.4\% powdered PF), was 0.36 $\mathrm{MPa}$ (Wan et al. 2007), which is slightly lower than the IB of the pine (Pine-S) in this research. Pre-impregnation of the strands before manufacturing of the panels compared to post-impregnation resulted in a significant $(\mathrm{p}<0.05)$ decrease of the IB from an average value of 0.70 to $0.50 \mathrm{MPa}$. Internal bond strength of Pre-S strandboard was not significantly different than Pine-S strandboard. Internal bond strength for post-impregnated panels (Post-S) was greater than the results for pine (Pine-S). The other strandboards made from juniper strands reached significantly higher IB in comparison to the pine strandboard. In all cases, the juniper strandboards had equal or greater internal bond strength than the pine strandboard.

Table 2. Average Values of Internal Bond Strength of Strandboard at $20^{\circ} \mathrm{C}$ and $65 \% \mathrm{RH}$

\begin{tabular}{|c|c|}
\hline Types of Strandboard & Internal Bond (MPa) \\
\hline Pine-S & $0.42(0.14) \mathrm{A}$ \\
\hline Mix-S & $0.60(0.14) \mathrm{B}, \mathrm{C}$ \\
\hline Sap-S & $0.90(0.12) \mathrm{E}$ \\
\hline Heart-S & $0.85(0.14) \mathrm{D}, \mathrm{E}$ \\
\hline Pre-S & $0.50(0.12) \mathrm{A}, \mathrm{B}$ \\
\hline Post-S & $0.70(0.12) \mathrm{C}, \mathrm{D}$ \\
\hline
\end{tabular}

Means with the same letter in column do not differ statistically by the Tukey's test $(\alpha=0.05)$. Numbers in parentheses represent standard deviation 


\section{CONCLUSIONS}

1. Juniper heartwood has long been recognized as highly durable. Results from this research indicate that strandboard made from juniper heartwood is also highly decay resistant. There appears to be very good potential for manufacturing juniper OSB, especially from heartwood, as a highly decay resistant product. Further, with respect to bond integrity, the findings indicate that impregnating juniper strands with juniper oil prior to pressing results in a significant reduction in internal bond strength compared to panels impregnated after pressing. However, the resulting average IB values for panels made from pre-impregnated strands are similar to those for southern yellow pine panels. Also, juniper strandboard manufactured from non-impregnated strands showed significantly higher internal bond values than pine.

2. One limitation of the research is that the amount of the sapwood in the manufacturing of the strandboards with mixed heartwood and sapwood was not measured. It seems that this is also very important and it can be a next step for better utilization of the juniper wood.

\section{ACKNOWLEDGMENTS}

This research was conducted as part of a project developed by Sustainable Northwest titled "Scaling Juniper Markets: Sustainable Solutions for Rangelands and Rural Communities." Funding was provided by Business Oregon via the High Impact Opportunities program.

\section{REFERENCES CITED}

Acda, M., Morrell, J. J., Silva, A., Levien, K. L., and Karchesy, J. (1998). "Using supercritical carbon dioxide for extraction of Western juniper and Alaska-cedar," Holzforschung 52(5), 472-474. DOI: 10.1515/hfsg.1998.52.5.472

Adams, R. P. (1987). "Investigation of Juniperus species of the United States for new sources of cedarwood oil," Economic Botany 41(1), 48-54. DOI: 10.1007/BF02859346

Adams, R. P. (2014). Junipers of the World: The Genus Juniperus, Trafford Publishing Co, Vancouver, Canada.

Adams, R. P., McDaniel, C. A., and Carter, F. L. (1988). "Termiticidal activities in the heartwood, bark/sapwood and leaves of Juniperus species from the United States," Biochemical Systematics and Ecology 16(5), 453-456. DOI: 10.1016/03051978(88)90043-9

ASTM D1037-12 (2020). "Standard test methods for evaluating properties of wood-base fiber and particle panel materials," ASTM International, West Conshohocken, PA, USA.

ASTM D2017-05 (2014). "Standard method of accelerated laboratory test of natural decay resistance of woods," ASTM International, West Conshohocken, PA, USA.

Ateş, S., Gür, M., Özkan, O. E., Akça, M., Olgun, Ç., and Güder, A. (2015). "Chemical contents and antifungal activity of some durable wood extractives vs. Pleurotus 
ostreatus," BioResources 10(2), 2433-2443. DOI: 10.15376/biores.10.2.2433-2443

AWPA E10-16. (2020). "Standard method of testing wood preservatives by laboratory soil-block cultures," American Wood Preservers' Association, Birmingham, AL, USA.

Bedell, T., Eddleman, L., Deboodt, T., and Jacks, C. C. (1993). Western Juniper: its Impact and Management in Oregon Rangelands, Oregon State University Extension Service, (https://ir.library.oregonstate.edu/concern/administrative_report_or_ publications/3t945r00n), Accessed 8 Jan 2021.

Craig, A. M., Karchesy, J. J., Blythe, L. L., González-Hernández, M. del P., and Swan, L. R. (2004). "Toxicity studies on western juniper oil (Juniperus occidentalis) and PortOrford-cedar oil (Chamaecyparis lawsoniana) extracts utilizing local lymph node and acute dermal irritation assays," Toxicology Letters 154(3), 217-224. DOI: 10.1016/j.toxlet.2004.08.004

Floudas, D., Binder, M., Riley, R., Barry, K., Blanchette, R. A., Henrissat, B., Martínez, A. T., Otillar, R., Spatafora, J. W., Yadav, J. S., et al. (2012). "The Paleozoic origin of enzymatic lignin decomposition reconstructed from 31 fungal genomes," Science 336(6089), 1715-1719. DOI: 10.1126/science. 1221748

Gedney, D. R., Azuma, D. L., Bolsinger, C. L., and Mckay, N. (1999). Western Juniper in Eastern Oregon (Gen. Tech. Rep. PNW-GTR-464), U.S. Department of Agriculture, Pacific Northwest Research Station, Portland, OR.

Goodell, B., Winandy, J. E., and Morrell, J. J. (2020). "Fungal degradation of wood: Emerging data, new insights and changing perceptions," Coatings 10(12), 1210. DOI: $10.3390 /$ coatings 10121210

Hemmerly, T. E. (1970). "Economic uses of eastern red cedar," Economic Botany 24(1), 39-41. DOI: $10.1007 / \mathrm{BF} 02860632$

Highley, T. L. (1995). "Comparative durability of untreated wood in use above ground," International Biodeterioration \& Biodegradation 35(4), 409-419. DOI: 10.1016/0964-8305(95)00063-1

Kirker, G. T., Blodgett, A. B., Arango, R. A., Lebow, P. K., and Clausen, C. A. (2013). "The role of extractives in naturally durable wood species," International Biodeterioration \& Biodegradation 82, 53-58. DOI: 10.1016/j.ibiod.2013.03.007

Kües, U. (2015). "Fungal enzymes for environmental management," Current Opinion in Biotechnology 33, 268-278. DOI: 10.1016/j.copbio.2015.03.006

Kurth, E. F., and Ross, J. D. (1954). Volatile Oil from Western Juniper, Oregon Forest Products Laboratory Rep. No. C-3, Oregon State University, Corvallis, OR, USA.

Lee, S.-Y., Kim, S.-H., Hong, C.-Y., Kim, H.-Y., Ryu, S.-W., and Choi, I.-G. (2015). "Biotransformation of (-)- $\alpha$-pinene by whole cells of white rot fungi, Ceriporia sp. ZLY-2010 and Stereum hirsutum," Mycobiology 43(3), 297-302, DOI: 10.5941/MYCO.2015.43.3.297

Lipeh, S., Schimleck, L. R., Mankowski, M. E., McDonald, A. G., and Morrell, J. J. (2020). "Relationship between attenuated total reflectance Fourier transform infrared spectroscopy of western juniper and natural resistance to fungal and termite attack," Holzforschung 74(3), 246-259. DOI: 10.1515/hf-2019-0096

Miyamoto, B. T., Konkler, M. J., Leavengood, S., Morrell, J. J., and Sinha, A. (2019). "Durability assessment of western juniper from five different growing regions," Wood and Fiber Science 51(1), 88-95. DOI: 10.22382/wfs-2019-009

Morrell, J. J. (2011). "Resistance of selected wood-based materials to fungal and termite attack in non-soil contact exposures," Forest Products Journal 61(8), 685-687. DOI: 
10.13073/0015-7473-61.8.685

Morrell, J., and Schneider, P. (1999). Service Life of Treated and Untreated Fence Posts: 1996 Post Farm Report (Research Contribution 26), Forest Research Laboratory, Oregon State University, Corvallis, OR, USA.

Mun, S. P., and Prewitt, L. (2011). "Antifungal activity of organic extracts from Juniperus virginiana heartwood against wood decay fungi," Forest Products Journal 61(6), 443-449. DOI: 10.13073/0015-7473-61.6.443

Orejuela, L. M. (1995). “Analysis of polymeric extractives of western juniper (Juniperus occidentalis) heartwood," Journal of Forest Research 13, 183-190.

Panshin, A., and Zeeuw, C. (1980). Textbook of Wood Technology: Structure, Identification, Properties, and Uses of the Commercial Wood of the United States and Canada ( $3^{\text {rd }}$ Ed.), McGraw Hill, New York.

Scheffer, T. C., and Morrell, J. J. (1998). Natural Durability of Wood: A Worldwide Checklist of Species (Research Contribution 22), Forest Research Laboratory, Oregon State University, Corvallis, OR, USA.

Scouse, A., Kamke, F. A., Morrell, J. J. (2015). "Potential for using essential oils to protect viscoelastic thermal compression-treated hybrid poplar," Forest Products Journal 65(3/4), 93-99.

Sichamba, K., Morrell, J. J., and Leavengood, S. (2012). "Potential for utilizing western juniper (Juniperus occidentalis) biomass for oil extraction and as a fermentation medium," Forest Products Journal 62(7-8), 538-540. DOI: 10.13073/FPJ-D-1200107.1

Swan, L., and Connolly, M. (1998). "Processing and finishing western juniper," in: Proc. Wood Technology Clinic and Show, Portland, OR, USA.

Swan, L. (1995). "Western juniper: An evolving case study in commercialization, ecosystem management, and community development," in: Desired Future Conditions for Pinon-Juniper Ecosystems (Gen. Tech. Rep. RM-258), D.W Shaw, E. F Aldon, and C. LoSapio (tech. coords.), U.S. Department of Agriculture, Forest Service, Fort Collins, CO, pp. 179-183.

Wan, H., Wang, X., and Yang, D. (2007). "Utilizing eastern white cedar to improve the resistance of strand boards to mold and decay fungi," Forest Products Journal 57(3), 54-59.

Zabel, R. A., and Morrell, J. J. (2020). Wood Microbiology: Decay and Its Prevention, $\left(2^{\text {nd }}\right.$ Ed.), Academic Press, Cambridge, MA, USA.

Article submitted: February 17, 2021; Peer-review completed: March 14, 2021; Revised version received and accepted: April 3, 2021; Published: April 13, 2021.

DOI: 10.15376/biores.16.2.3886-3894 